\title{
Efektivitas Pemberian IAA, IBA, NAA, dan Root-up pada Pembibitan Kesemek
}

\author{
Effectiveness of IAA, IBA, NAA and Root-up Application on Persimmon Seedling \\ Eko Setiawan
}

Diterima 19 September 2016/Disetujui 10 Juli 2017

\begin{abstract}
Oriental persimmon (Diospyros kaki L.) originated from and has mainly been cultivated in China, Korea, and Japan, and currently it is cultivated in Batu, Kuningan, and Brastagi regions, Indonesia. Success in propagating persimmon in Indonesia has been limited. The objective of the study was to determine propagation techniques through root cutting supplemented with auxin treatment. All seedlings from root stock cutting supplemented with 100 ppm of either indoleacetic acid (IAA), indolebutyric acid (IBA), $\alpha$-napthaleneacetic acid (NAA), or Root-up, and control. The results showed bud form stem or root cuttings treated with IAA, NAA and Root-up 100 ppm emerged earlier than IBA $100 \mathrm{ppm}$ and control. The percentage of mortality of Root-up $100 \mathrm{ppm}$ treatment and control cuttings was the highest (50\%) than the others treatments. IAA and IBA treatments stimulated larger number of shoot, 16.5 and 17.0 shoots, respectively. The number of leaves was higher in plant treated with IAA 100 ppm (20.8 leaves).
\end{abstract}

Keywords: auxin, Diospyros kaki L., germination, leaf number, root stock

\begin{abstract}
ABSTRAK
Tanaman kesemek atau oriental persimmon (Diospyros kaki L.) banyak dibudidayakan di China, Korea, serta Jepang, dan saat ini banyak ditanam di Indonesia seperti di daerah Batu, Kuningan, dan Brastagi. Keberhasilan pembibitan kesemek di Indonesia masih rendah. Penelitian bertujuan untuk memperbanyak tanaman secara vegetatif dari pemisahan tunas akar dengan perlakuan auksin guna mendukung pengembangan pembibitan tanaman kesemek. Perbanyakan tanaman dilakukan dengan tunas akar yang direndam dengan auksin (IAA, IBA, NAA, dan Root-up; masing-masing $100 \mathrm{ppm}$ ), serta perlakuan kontrol. Hasil penelitian menunjukkan perlakuan IAA, NAA dan Root-up 100 ppm menghasilkan tunas lebih awal dibandingkan dengan kontrol dan IBA 100 ppm. Tingkat kematian bibit tertinggi mencapai 50\% terjadi pada perlakuan Root-up 100 ppm dan kontrol. Jumlah tunas terbanyak dihasilkan oleh perlakuan IAA dan IBA sebanyak 16.5 dan 17.0 tunas. Jumlah daun terbanyak dihasilkan oleh perlakuan IAA 100 ppm (20.8 helai).
\end{abstract}

Kata kunci: auksin, Diospyros kaki L., jumlah daun, muncul tunas, tunas akar

\section{PENDAHULUAN}

Kesemek disebut Oriental (Chinese/Japanese) persimmon, dan nama ilmiahnya adalah Diospyros kaki L. (Akagi, 2011) merupakan tanaman buah subtropik (İncesu et al., 2015). Di Indonesia, kesemek ditanam di dataran tinggi seperti daerah Malang, Majalengka, Garut, Kuningan, Karo,
Toba serta Solok (Santosa et al., 2005), tetapi saat ini juga dikembangkan di daerah Cisurupan, Garut, Ciloto, Boyolali, Temanggung, Magelang, dan Magetan (Pitojo dan Puspita, 2007). Menurut Zenginbal (2015), selain dimakan sebagai buah meja, kesemek juga sudah dijadikan bahan es krim, minuman, bahan kosmetik, manisan atau selai, dan pohonnya dapat digunakan sebagai pendukung 
lansekap serta penahan erosi. Negara-negara utama penghasil kesemek yaitu China, Jepang, Brazilia, Korea, dan Italia (Zenginbal, 2015).

Menurut Santosa et al. (2005) alasan kesemek tidak berkembang pesat di Indonesia adalah: (1) tanaman kesemek ditanam di sekitar pekarangan, (2) terbatasnya areal kebun di dataran tinggi, dan (3) harga buah kesemek yang rendah sehingga sebagian besar petani pada tahun 1980-an mengganti kebun kesemek miliknya dengan tanaman sayuran. Petani menanam tanaman kesemek untuk menjaga kestabilan pendapatan karena tanaman sayuran mengalami fluktuasi harga setiap tahunnya. Sulitnya perbanyakan bibit kesemek menjadi sebab lain produksi dan areal penanaman terbatas di Indonesia.

Salah satu penyebab konsumen di Indonesia kurang tertarik pada buah kesemek adalah warna putih dari kapur yang menutupi kulit buah. Kesemek identik dengan buah yang mengandung tanin dan rasa sepat (Heras et al., 2016), tetapi saat ini sudah banyak kultivar yang mempunyai kadar tanin rendah (Min et al., 2012). Beberapa metode untuk menghilangkan sifat astringency yaitu dengan perendaman buah kesemek pada larutan kalsium oksida selama lima hari (Santosa et al., 2005), serta menyemprot buah kesemek dengan alkohol (Setiawan, 2014). Saat ini di Jepang sudah dikembangkan bibit kesemek non-astringent dengan penampilan menarik (Koshita et al., 2007) hasil persilangan kultivar 'Taigetsu' dengan 'Kanshu' (Mitani et al., 2014). Perbanyakan kesemek di Indonesia biasanya melalui pemisahan tunas akar (Santosa et al., 2005). Di daerah subtropik, perbanyakan kesemek biasanya dilakukan dengan sambungan mata tunas dewasa yang ditempelkan pada batang bawah yang berasal dari biji (Tetsumura et al., 2010).

Untuk itu ketersediaan jumlah bibit yang bermutu dalam jumlah yang banyak, cepat dan seragam merupakan langkah awal pengembangan tanaman kesemek terutama di beberapa daerah baru. Pemberian auksin dapat mempercepat pembentukan akar (Guo et al., 2009). Publikasi dan informasi tentang pengembangan kesemek di Indonesia masih terbatas. Tujuan penelitian ini ialah mengetahui pengaruh pemberian auksin terhadap keberhasilan pembibitan tanaman kesemek. Kemudahan penyediaan bibit tanaman kesemek diharapkan mampu mendorong minat masyarakat untuk mengembangkan tanaman kesemek.

\section{BAHAN DAN METODE}

Penelitian dilaksanakan di Laboratorium Produksi Fakultas Pertanian, Universitas Trunojoyo pada Juni sampai Desember 2015. Bibit kesemek adalah tunas akar umur 18 bulan, dengan tinggi sekitar $50 \mathrm{~cm}$ dan diameter batang $\pm 0.5 \mathrm{~cm}$ (Gambar 1). Bibit diambil dari kebun milik petani kesemek di Batu, Malang. Tunas akar dipisahkan dari induknya dengan cara pangkal batang dipotong, kemudian bekas potongan direndam pada larutan sesuai perlakuan selama 5 menit.

Rancangan penelitian yang digunakan adalah Rancangan Acak Lengkap (RAL) faktor tunggal dengan 5 perlakuan auksin masing-masing 100 ppm yaitu: indoleacetic acid (IAA), indolebutyric acid (IBA), $\alpha$ napthaleneacetic acid (NAA), dan Root-up (merek dagang zat pengatur tumbuh untuk mendorong pertumbuhan akar); dan kontrol (tanpa diberi apa-apa), yang diulang 6 kali. Setiap unit percobaan terdiri atas 6 bibit tanaman kesemek. Root-up mengandung bahan aktif: 1-Naftalenasetamida $0.20 \%$; 2 Metil-1-naftalen asetat $0.03 \%$; Indol-3-butirat $0.06 \%$; dan Thiram $4.0 \%$. Bibit ditanam di polibag ukuran $40 \mathrm{~cm} \times 50 \mathrm{~cm}$ dengan media campuran tanah : pasir : pupuk kotoran kambing (1:1:1) kemudian dipelihara di bawah naungan paranet $50 \%$.

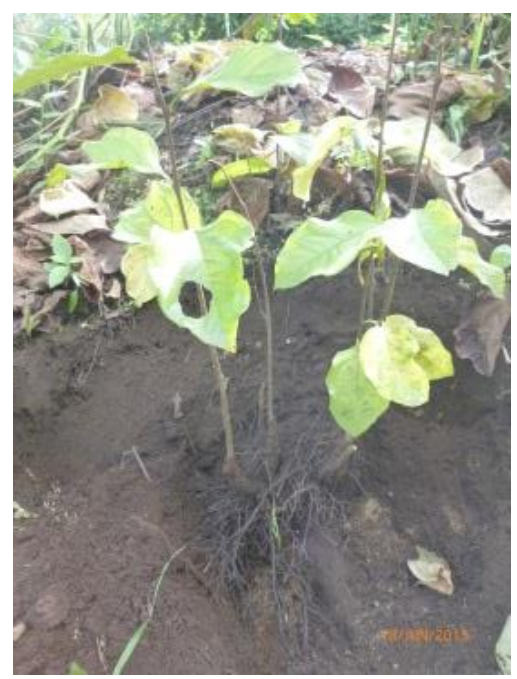

Gambar 1. Tunas akar kesemek yang akan dipotong untuk dijadikan bibit. 
Pengamatan terhadap waktu munculnya tunas diamati setiap hari. Jumlah daun, jumlah tunas diamati setiap seminggu setelah muncul tunas. Pemeliharaan meliputi penyiraman setiap pagi dan sore hari. Pengamatan dilakukan sampai seluruh bibit tanaman kesemek muncul tunas baru dan daun berkembang sempurna. Data yang diperoleh dianalisis menggunakan ANOVA. Apabila terdapat pengaruh perlakuan maka dilanjutkan menggunakan DMRT 5\%.

\section{HASIL DAN PEMBAHASAN}

Perlakuan IAA, Root-up, dan NAA secara signifikan mempercepat muncul tunas bibit tanaman kesemek yaitu rata-rata pada 18 , 19, dan 25 hari secara berurutan (Gambar 2). Pecah tunas pada perlakuan IBA mulai terjadi pada hari ke-40 sedangkan pada kontrol pada hari ke-70. Peche et al. (2016) menyatakan stek kesemek yang disimpan dalam cold storage mengalami penurunan kandungan pati yang dikonversi menjadi gula terlarut dalam waktu 12-60 hari setelah stek dipotong, kemudian kandungan pati meningkat kembali setelah 72 hari karena terjadinya pencegahan pecah tunas pada batang stek kesemek yang beradaptasi dengan suhu dingin cold storage. Hal tersebut menjelaskan bahwa pada perlakuan kontrol mengalami pecah tunas terjadi lebih lambat dibanding perlakuan auksin. Epstein dan Ludwig-Muller (1993) menyatakan transport pada auksin menunjukkan bahwa IAA diangkut lebih cepat dibanding NAA dan IBA, secara berurutan yaitu $7.5 \mathrm{~mm} \mathrm{~h}^{-1}, 6.7 \mathrm{~mm} \mathrm{~h}^{-1}$, dan $3.2 \mathrm{~mm} \mathrm{~h}^{-1}$ dengan arah basipetal. Hal tersebut menjelaskan waktu muncul tunas pada bibit kesemek dengan perlakuan IAA dan NAA lebih cepat dibanding perlakuan IBA. Pemberian $0.1 \mu \mathrm{M}$ IAA pada perbanyakan bibit kesemek kultivar 'Jiro' dan 'Saijo' asal kalus mampu membentuk primordia daun, sedangkan penanaman dari biji memerlukan konsentrasi $10 \quad \mu \mathrm{M}$ IAA (Yakushiji dan Nakatsuka, 2007). Penggunaan $0.25 \mathrm{mg} \mathrm{L}^{-1}$ zeatin dan $0.125 \mathrm{mg} \mathrm{L}^{-1}$ IAA mampu menginisiasi tunas lebih cepat pada tomat (Ningsih et al., 2016).

Perbanyakan kesemek dengan stek sangat sulit berhasil (Yamada, 2008), sedangkan pemisahan tunas akar mempunyai tingkat keberhasilan yang tinggi (Yakushiji dan Nakatsuka, 2007).

Perlakuan IAA, IBA, dan NAA secara signifikan mampu mempertahankan sebanyak 83.3\% bibit hidup (Gambar 3). Penggunaan IBA dan NAA pada stek jambu biji mampu mempertahankan bibit hidup sebesar 92\% (Kareem et al., 2013). IBA dan NAA lebih sering digunakan untuk pembibitan karena harganya lebih murah dibanding IAA (Waheed et al., 2015). Perbedaan jenis auksin diduga menyebabkan perbedaan pembentukan akar pada tanaman. Pada tanaman yang terbentuk akar, tingkat kematian tanaman rendah (Guo et al., 2009). Pada perlakuan Root-up dan kontrol tingkat tanaman hidup sebesar 50\%. Yakushiji dan Nakatsuka (2007), penggunaan $250 \mathrm{mg} \mathrm{L}^{-1}$ IBA dan $0.2 \mathrm{M}$ fruktosa dengan media MS mampu membentuk perakaran pada bibit kesemek sebesar 94\%. Bibit kesemek asal kalus akan menghasilkan tunas setelah dua bulan (Yokoyama et al., 2011).

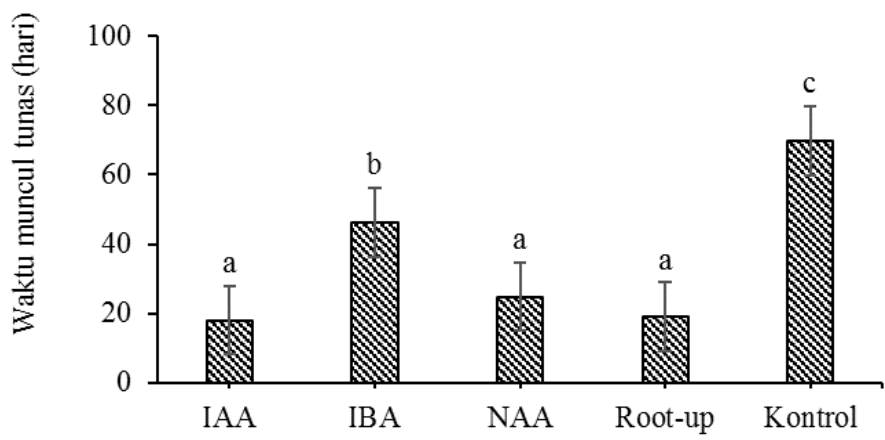

Gambar 2. Waktu munculnya tunas pada bibit tanaman kesemek pada perlakuan jenis auksin. Bar \pm SE. 


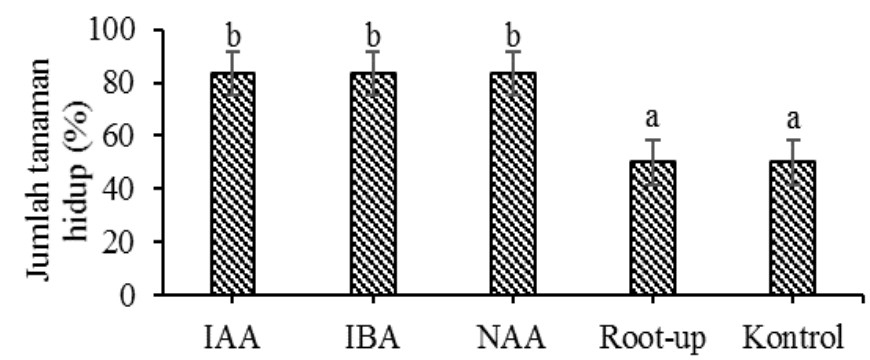

Gambar 3. Jumlah bibit tanaman kesemek hidup pada perlakuan jenis auksin. Bar \pm SE.

Perlakuan IAA dan IBA secara signifikan mendorong pertumbuhan tunas yang tinggi pada minggu pertama dan kedua, kemudian jumlah tunas menurun mulai minggu ke-3 dan seterusnya (Gambar 4). Perlakuan IAA dan IBA menghasilkan jumlah tunas rata-rata 2.7 dan 2.8 buah per minggu. Total tunas yang dihasilkan perlakuan IAA dan IBA hingga minggu keenam masingmasing sebanyak 16.5 dan 17.0 tunas. Tren penambahan jumlah tunas pada perlakuan NAA dan Root-up rendah pada minggu pertama, kemudian meningkat pada minggu kedua dan relatif konstan pada mingguminggu berikutnya. Kontrol menghasilkan jumlah tunas paling rendah dibandingkan dengan perlakuan yang lainnya, hingga minggu kedua sampai kelima adalah 2 buah. Flicklin dan Shelton (2007) melaporkan jumlah tunas baru yang dihasilkan pada bibit kesemek yang dipangkas rata-rata sebesar 3.2 tunas. Ali et al. (2009) menyatakan IBA lebih efektif untuk pembibitan zaitun dibandingkan dengan NAA, hal itu disebabkan pelepasan IBA terjadi lebih lambat dan dilepaskan secara hidrolisis konjugat. Hidrolisis konjugat ini menyebabkan IBA dikonversi menjadi IAA yang terkait dengan asam amino, gula atau peptida (Woodward and Bartel, 2005), sehingga lebih superior dibandingkan NAA dalam membentuk perakaran dan pertumbuhan lebih lanjut dari bibit (Enders and Strader,
2015). Ali et al. (2009) menyatakan IAA kinerjanya 20-30 kali lebih tinggi jika dibandingkan tanpa pemberian auksin. Efek inferior NAA dari IBA menjelaskan bahwa NAA tetap berada dalam jaringan bibit tanaman sehingga menghambat perkembangan selanjutnya dari perkembangan meristem akar (Ali et al., 2009). Hal tersebut menjelaskan mengapa perlakuan Root-up tidak memberikan hasil sebaik IAA dan IBA, karena Root-up cenderung menyerupai kerja dari NAA.

Pada perlakuan IAA, tanaman mempunyai jumlah daun yang terbanyak dibandingkan perlakuan yang lainnya, diikuti perlakuan NAA dan IBA yaitu secara berurutan sebanyak 20.8, 10.6, dan 13 helai (Gambar 5). Perlakuan kontrol dan Root-up mempunyai jumlah daun yang terendah yaitu sejumlah 4.0 dan 4.9 helai. Yakushiji dan Nakatsuka (2007) melaporkan sejumlah $90 \%$ bibit kesemek yang ditanam di greenhouse mampu bertahan hidup jika mempunyai daun sejumlah tiga atau lebih. Hal ini menjelaskan pada perlakuan kontrol dan Root-up, bibit kesemek mempunyai jumlah daun yang rendah sehingga jumlah tanaman yang hidup juga lebih rendah dibandingkan perlakuan IAA, IBA, dan NAA. Guo et al. (2009) menyatakan IAA merupakan merupakan pendorong utama untuk aktivitas pembentukan akar pada tanaman daripada IBA pada konsentrasi yang sama.

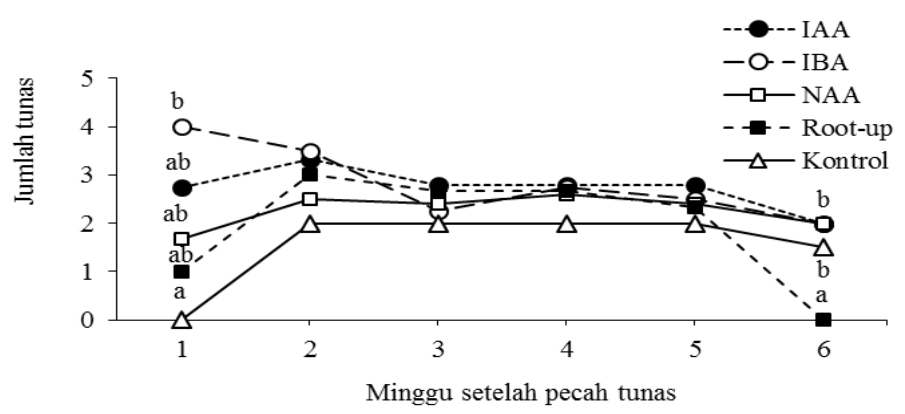

Gambar 4. Jumlah tunas per bibit tanaman kesemek pada perlakuan jenis auksin. 


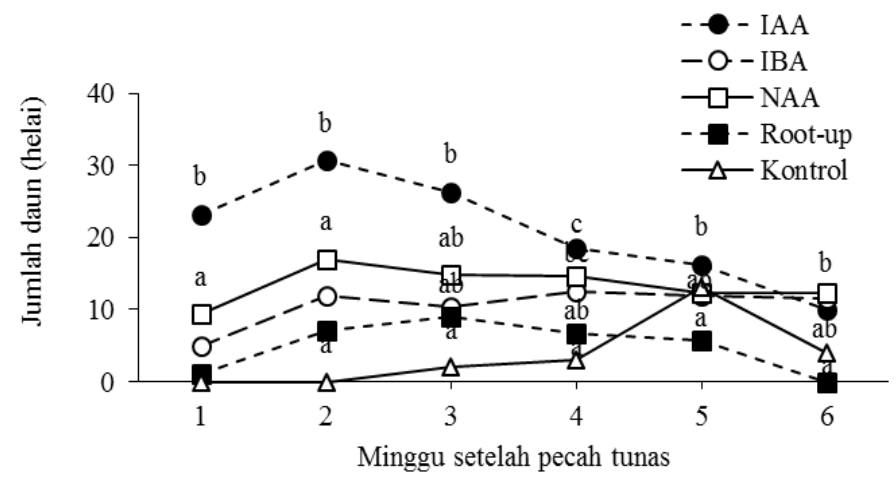

Gambar 5. Jumlah daun per bibit tanaman kesemek pada perlakuan jenis auksin.

\begin{abstract}
Respon pembentukan akar yang selanjutnya mempengaruhi pertumbuhan tunas, daun dan organ lainnya sangat dipengaruhi oleh jenis auksin, konsentrasi dan genotipe tanaman (Guo et al., 2009). Penggunaan $0.4 \%$ NAA pada bibit kesemek yang dibudidayakan pada media MS dilaporkan sebanyak 25 dari 95 kultivar kesemek gagal membentuk akar, sedangkan penggunaan IBA secara in vitro lebih efektif pada kondisi gelap (Palla et al., 2013). IBA mampu membantu pembentukan akar kesemek secara baik pada kondisi in vitro tetapi tidak pada kondisi in vivo (Kochanová et al., 2011).

Kondisi lingkungan (suhu dan kelembaban) dalam perbanyakan vegetatif sangat berpengaruh terhadap pembentukan kalus dan pertumbuhan bibit (Yulianto et al., 2015). Pada penelitian suhu di pagi hari sekitar $27.8{ }^{0} \mathrm{C}$ dengan kelembaban sebesar $88.7 \%$, sedangkan pada siang hari suhunya meningkat menjadi $33.3{ }^{\circ} \mathrm{C}$ dan kelembabannya turun menjadi $72 \%$. Kelembaban tanah dipengaruhi langsung oleh sinar matahari yang diterima, dan kelembaban tanah selanjutnya akan mempengaruhi pertumbuhan bibit kesemek terutama dalam pembentukan akar (Ficklin dan Shelton, 2007). Intensitas cahaya sangat penting untuk tingkat keberhasilan hidup dan pertumbuhan bibit, selama aklimatisasi bibit kesemek yang hidup mencapai $85 \%$ pada suhu $28{ }^{0} \mathrm{C}$ dengan pencahayaan 60 atau $120 \mu \mathrm{mol}$ $\mathrm{m}^{-2} \mathrm{~s}^{-1}$ (Yakushiji dan Nakatsuka, 2007).
\end{abstract}

\section{KESIMPULAN}

Pemberian IAA dapat digunakan untuk memacu pertumbuhan bibit tanaman kesemek asal tunas akar. IAA mampu mempercepat pertumbuhan tunas lebih cepat (18 hari), tingkat kematian bibit rendah (16.7\%), jumlah tunas yang tinggi (16.5 buah) serta jumlah daun yang dihasilkan cukup tinggi (20.8 helai).

\section{DAFTAR PUSTAKA}

Akagi, T., A.K. Ikegami, K. Yonemori. 2011. Proanthocyanidin biosynthesis of persimmon (Diospyros kaki Thunb.) fruit. Sci. Hort. 130: 373-380.

Ali, A., T. Ahmad, N.A. Abbasi, I.A. Hafiz. 2009. Effect of different concentrations of auxins on in vitro rooting of olive cultivar 'Moraiolo'. Pak. J. Bot. 41(3): 1223-1231.

Enders, T.A., L.C. Strader. 2015. Auxin activity: past, present, and future. Americ. J. Bot. 102(2): 180-196.

Epstein, E., J. Ludwig-Muller. 1993. Indole-3butyric acid in plants: occurrence, synthesis, metabolism and transport. Physiol. Plant. 88: 382-389.

Flicklin, R.L., M.G. Shelton. 2007. Effects of light regime and season of clipping on the growth of cherrybark oak, white oak, persimmon, and sweetgum sprouts. J. Arkansas Aca. Sci. 61(9): 51-58.

Guo, X.F., X.L. Fu, D.K. Zang, Y. Ma. 2009. Effect of auxin treatments, cuttings, collection date and initial characteristics on Paeonia 'Yang Fei Chu Yu' cutting propagation. Sci. Hort. 199: 177-181.

Heras, R.M-L, J.C. A-Sánchez, A. Heredia, M.L. Castelló, A. Andrés. 2016. 
Influence of preharvest treatments to reduce the seasonality of persimmon production on color, texture and antioxidant properties during storage. CyTA J. Food. 14(2): 333-339.

İncesu, M., T. Yeşiloğlu, B. Çimen, B. Yilmaz, Ç. Akpinar, İ. Ortaş. 2015. Effects on growth of persimmon (Diospyros virginiana) rootstock of arbuscular mycorrhizal fungi species. Turk. J. Agric. For. 39: 117-122.

Kareem, A., M.J. Jaskani, B. Fatima, B. Sadia. 2013. Clonal multiplication of guava through softwood cuttings under mist conditions. Pak. J. Agri. Sci. 50(1): 2327.

Kochanová, Z., N. Onus, J. Brindza. 2011. Adventitious shoot regeneration from dormant buds of persimmon (Diospyros kaki Thunb.) cv. Hachiya. J. Agrobiol. 28(2): 113-118.

Koshita, Y., K. Morinaga, Y. Tsuchida, T. Asakura, H. Yakushiji, A. Azuma. 2007. Selection of interstocks for dwarfing Japanese persimmon (Diospyros kaki Thunb.) trees. J. Japan. Soc. Hort. Sci. 76(4): 288-293.

Mitani, N., A. Kono, M. Yamada, A. Sato, S. Kobayashi, Y. Ben, T. Ueno, M. Shiraishi, S. Kanzaki, T. Tsujimoto, K. Yonemori. 2014. Application of markerassisted selection in persimmon breeding of PCNA offspring using SCAR markers among the population from the cross between Non-PCNA 'Taigetsu' and PCNA 'Kanshu'. Hort. Sci. 49(9): 1132-1135.

Min, T., X. Yin, Y. Shi, Z. Luo, Y. Yao, D. Grierson, I.B. Ferguson, K. Chen. 2012. Ethylene-responsive transcription factors interact with promoters of $\mathrm{ADH}$ and PDC involved in persimmon (Diospyros kaki) fruit de-astringency. J. Exp. Bot. 63(18): 6393-6405.

Ningsih, R., B.S. Purwoko, M. Syukur, I.S. Dewi. 2016. Induksi kalus dan regenerasi tiga genotipe tomat (Solanum lycopersicon L.) melalui kultur antera. J. Hort. Indonesia. 7(2): 75-82.

Palla, K.J., R.R. Beasley, P.M. Pijut. 2013. In vitro culture and rooting of Diospyros virginiana L. Hort. Sci. 48(6): 747-749.

Peche, P.M., A.L. Figueiredo, R. Pio, C.A. Andrade, E.T. de-Melo, C.A.de-A. Barbosa. 2016. Cold storage of budsticks/clefts for staggered grafting in persimmon trees. Ciência Rural. 46(8): 1344-1349.

Pitojo, S., H.N. Puspita. 2007. Kesemek. Kanisius, Yogyakarta.

Santosa, E., N. Sugiyama, M. Nakata, S. Kawabata, N. Kubota. 2005. Cultivation of Japanese persimmon in West Java, Indonesia. Japan. J. Trop. Agr. 49(3): 220-226.

Setiawan, E. 2014. Perbaikan kualitas buah kesemek dengan penyemprotan alkohol. Agrovigor. 7(2): 121-125.

Tetsumura, T., S. Haranoushiri, T. Marume, C. Torgoe, T. Omori, Y. Kurogi, Y. Uchida, C. Honsho. 2010. Orchard growth, flowering and fruiting of 'Fuyu' and 'Hiratanenashi' Japanese persimmon trees grafted on potensially dwarfng rootstocks propagated by cutting. J. Japan. Soc. Hort. Sci. 79(4): 327-334.

Waheed, A., F.S. Hamid, H. Ahmad, F.M. Abbasi, S. Aslam, A.H. Shah, N. Ahmad, Z. Naheed, H. Ali, N. Khan. 2015. Effect of indole butyric acid (IBA) on early root formation (tomato 'Sahil' hybrid) cuttings. J. Mater. Environ. Sci. 6(1): 272-279.

Woodward, A.W., B. Bartel. 2005. Auxin: regulation, action, and interaction. Ann. Bot. 95: 707-735.

Yakushiji, H., A. Nakatsuka. 2007. Recent persimmon research in Japan. Japan. J. Plant Sci. 1 (2): 42-62. 
J. Hort. Indonesia 8(2): 97-103. Agustus 2017.

Yamada, M. 2008. Persimmon propagation, orchard planting, training and pruning in Japan. Adv. Hort. Sci. 22(4): 269-273.

Yokoyama, T., Y. Moriyasu, Y. Sugawara. 2011. Adventitious bud formation through nodule induction by thidiazuron in cultured leaf segments of the Japanese persimmon (Diospyros kaki Thunb.). Plant Biotech. 28: 339-344.
Yulianto, A.G., E. Setiawan, K. Badami. 2015. Efek pemberian IBA terhadap pertautan sambung samping tanaman srikaya. Agrovigor. 7(2): 51-56.

Zenginbal, H. 2015. The effects of grafting methods (by hand and with manual grafting unit) and grafting times on persimmon (Diospyros kaki L.) propagation. Acta Sci. Pol. Hort. Cul. 14(4): 39-50. 